空力弾性翼の能動制御におけるセンサ位置と零点*1

\title{
Sensor Location and Zeros in Active Control of Aeroelastic Airfoils
}

\author{
太田裕 文*2 \\ Hirobumi OHTA and Masataka YAMADA
}

Key Words : Aeroelasticity, ACT, Sensor Location and Zeros

\begin{abstract}
Transfer function zeros of active control systems are studied for a two dimensional typical airfoil in an incompressible flow. Both steady and unsteady aerodynamics are used for the modeling of the dynamics. Sensor location which gives us a minimum phase transfer function is examined over the airfoil area between the leading edge and the hinge line of the tailing edge control surface. Three types of zeros exist in the transfer function with an unsteady aerodynamic modeling. It is shown that the zeros corresponding to the ones derived from the steady aerodynamics determine an upper and lower boundaries of the flight velocity through which the transfer function changes its phase characteristics. The zeros that are originally contained in the unsteady aerodynamic modeling do not contribute to the phase change. However, two other zeros that are generated through the modeling determine a front boundary of the sensor location. It is to be noted in flutter control systems that a zero always exists near the critical pole and the transfer function shows a situation of near pole-zero cancellation around the flutter point.
\end{abstract}

$$
\text { 主な 記 号 }
$$

$a:$ 翼弦中心から弾性軸まで無次元距離

$b:$ 半弦長

$c:$ 翼弦中心から後縁操舵面ヒンジ線までの無次 元距離

$e=1 / 2+a$

$h:$ 曲げ変位 (下向き正), $\bar{h}=h / b$

$K$ : 換算速度 $(=U / b)$

$k=b \omega / U$, 無次元振動数

$l:$ 弾性軸からセンサまでの無次元距離

$l^{\prime}:$ 翼弦中心からセンサまでの無次元距離

$r_{\alpha}^{2}$ : 無次元慣性モーメント

\footnotetext{
${ }^{* 1}$ 平成 6 年 10 月 28 日，第 11 回誘蟞制御シンポジウムで発 表. 平成 6 年 11 月 26 日原稿受理

*2 名古屋大学工学部

*3 名古屋大学大学院工学研究科 (現 : トヨ夕自動車(株))
}

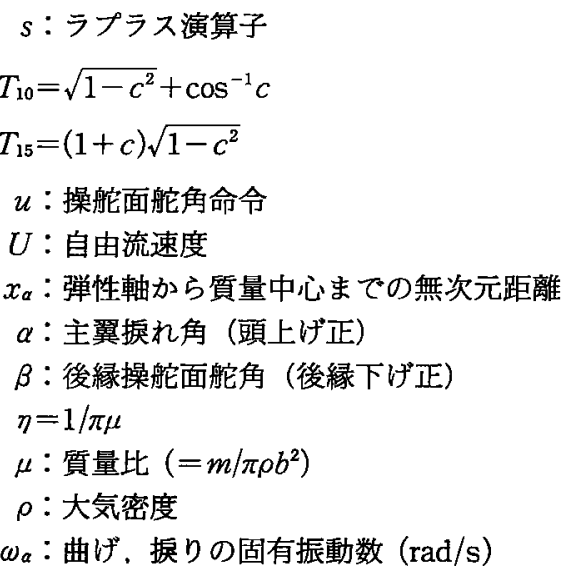

\section{1. 序}

論

航空機の翼のような弾性体の振動制御問題におい て, 外部入力から出力までの伝達関数の極注各振動乇 ードの振動数や減衰比を表し，その複素平面上の位置 によって対応するモードの安定性を知ることができ る. 一方, 伝達関数の零は出力の測定位置により変化 し，複素平面上の右半面に零が現れる非最小位相系で は制御性能に様々な悪影響を及涩すことが知られてい る．その一例としては逆応答や低感度化できるバンド 幅制限などがある．従って，あらかじめ出力位置の選 び方と零の挙動の関係を知ることは大変重要である.

空力弾性翼をその変動に応じて操舵面を動かすこと により制御する突風荷重軽減や能動フラッタ制御問題 では，極に注目して安定性や制御効果を述べている文 献は数多いが1)，零について述べているのは Edwards $ら^{2)}$, Liebst ${ }^{3)}$ ぐらいで, それも特定の翼構造諸元で の検討に止っており，一般の翼構造諸元と零との関係 については明らかになっていない。

本論文では，非圧縮流中の二次元翼上に置いたセン サ出力を後縁操舵面にフィードバックして能動制衔を 行う場合につき，センサ位置と零との関係を検討し， 
最小位相系となるセンサ範囲について明らかにする。 またこの応用の一例として能動フラッタ制御系を構成 し，センサ位置選択の重要性を指摘する。

\section{2. 二次元翼の基礎方程式}

第 1 図のような一様流速 $U$ 中の二次元平板翼を考 える(図中のS.P., C.G., M.C.はそれぞれセンサ，重 心，翼弦中心位置を表す)。この運動方程式は，基準 位固からの弾性軸 (E.A.) の曲げ変位 $h$ と㨭り角 $\alpha$ を 変数とすると,

$$
\boldsymbol{M}_{\mathrm{s}} \ddot{\overline{\boldsymbol{q}}}+\boldsymbol{K}_{\mathrm{s}} \overline{\boldsymbol{q}}=\frac{\eta}{\rho b^{4}} \boldsymbol{Q}
$$

と表現される.ここで後縁操舵面ヒンジまわりの捱り 剛性は無視し，さらに操舵面の重心はヒンジ線に一致 するものと仮定している．また，

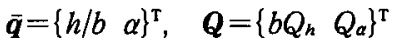

$$
\begin{aligned}
& \boldsymbol{M}_{\mathrm{s}}=\left[\begin{array}{cc}
1 & x_{\alpha} \\
x_{a} & r_{a}{ }^{2}
\end{array}\right], \quad \boldsymbol{K}_{\mathrm{s}}=\left[\begin{array}{cc}
\omega_{h}{ }^{2} & 0 \\
0 & r_{a}{ }^{2} \omega_{a}{ }^{2}
\end{array}\right]
\end{aligned}
$$

(1) 式右辺の一般空気力項 $\boldsymbol{Q}$ は，翼変動に伴う空 気力である。これを二次元非圧縮性非定常空気力理 論4)より，周波数領域で表すと，

$$
\boldsymbol{Q}=\rho b^{4}\left[K C(i k) \boldsymbol{R} \boldsymbol{Q}_{\mathrm{c}}(s)+\boldsymbol{Q}_{\mathrm{nc}}(s)\right]
$$

となる.ここで $K$ は換算速度 $U / b$ を表し, 空気力の 循環荷重成分 $Q_{c}$ と非循環荷重成分 $\boldsymbol{Q}_{\mathrm{nc}}$ は,

$$
\begin{aligned}
& \boldsymbol{Q}_{\mathrm{c}}=K \boldsymbol{E}_{1} \overline{\boldsymbol{q}}(s)+\boldsymbol{E}_{2} s \overline{\boldsymbol{q}}(s)+\boldsymbol{E}_{\boldsymbol{\beta}} \boldsymbol{x}_{\beta}(s) \\
& \boldsymbol{Q}_{\mathrm{nc}}=K \boldsymbol{B}_{\mathrm{nc}} s \overline{\boldsymbol{q}}(s)+\boldsymbol{M}_{\mathrm{nc}} s^{2} \overline{\boldsymbol{q}}(s)+\boldsymbol{Q}_{\mathrm{nc} \beta} \boldsymbol{x}_{\boldsymbol{\beta}}(s)
\end{aligned}
$$

と記述される.ただし，

$$
\begin{aligned}
& \boldsymbol{x}_{\beta}(t)=\left\{\begin{array}{lll}
\beta & \dot{\beta} & \ddot{\beta}
\end{array}\right\}^{\mathrm{T}} \\
& \boldsymbol{R}=\left[\begin{array}{ll}
-2 \pi & 2 \pi(1 / 2+a)
\end{array}\right]^{\mathrm{T}} \\
& \boldsymbol{E}_{1}=\left[\begin{array}{ll}
0 & 1
\end{array}\right], \quad \boldsymbol{E}_{2}=\left[\begin{array}{ll}
1 & 1 / 2-a
\end{array}\right] \\
& \boldsymbol{E}_{\beta}=\left[\begin{array}{lll}
T_{10} / \pi & T_{11} / 2 \pi & 0
\end{array}\right]
\end{aligned}
$$

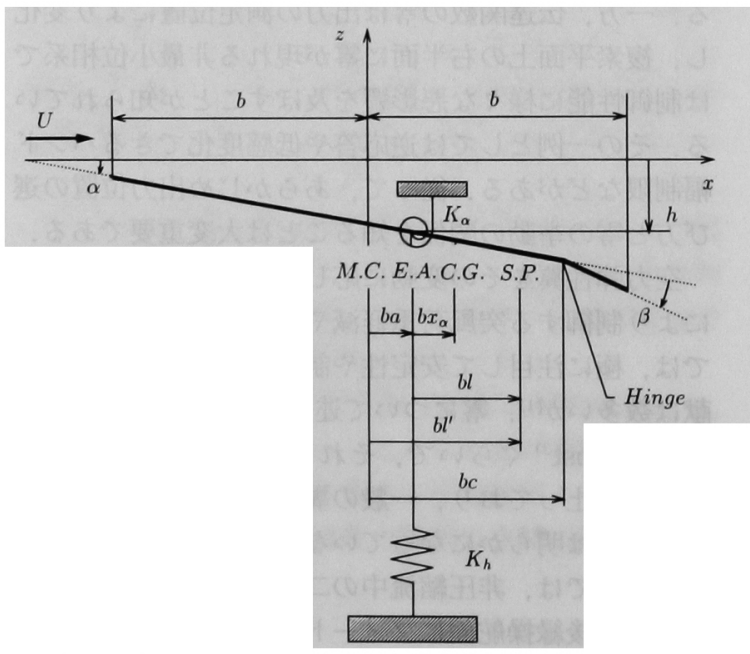

第 1 図 後縁操舵面付二次元䨘と記号

$$
\begin{aligned}
& \boldsymbol{B}_{\mathrm{nc}}=\left[\begin{array}{cc}
0 & -\pi \\
0 & -\pi(1 / 2-a)
\end{array}\right] \\
& \boldsymbol{M}_{\mathrm{nc}}=\left[\begin{array}{cc}
-\pi & \pi a \\
\pi a & -\pi\left(1 / 8+a^{2}\right)
\end{array}\right] \\
& \boldsymbol{Q}_{\mathrm{nc} \beta}=\left[\begin{array}{ccc}
0 & K T_{4} & T_{1} \\
-K^{2} T_{15} & -K T_{16} & -2 T_{13}
\end{array}\right]
\end{aligned}
$$

上式の行列中の $T_{1}, T_{4}, T_{10}$ 等は $T$ 関数と呼ばれ， $a$ とcのみにより記述される関数であり，詳しくは文 献 4)に収録されている。

Theodorsen 関数 $C(i k)$ は翼の調和振動を仮定して 導出されたものである.しかし，インデシアル荷重 関数の誘導に関するSearsの研究を基礎とし， Edwards ら ${ }^{2)}$ は解析接続によって調和振動のみならず 発散・収束振動に括いても $i k \rightarrow \bar{s}(=s b / U)$ として負の 実軸上を除くすぺての複素平面で $C(\bar{s})$ が評価できる ことを示し，これを一般化 Theodorsen 関数と呼んで いる.これを有理伝達関数で近似表現するため R. T. Jones の Wagner 関数の指数近似をもとにすれば,

$$
C(\bar{s})=0.5+\frac{0.10805 \bar{s}+0.006825}{\bar{s}^{2}+0.3455 \bar{s}+0.01365}
$$

と表現され，さらに(5)式を状態空間表現すると次式 が得られる。

$$
\begin{aligned}
& \dot{\boldsymbol{x}}_{\mathrm{a}}=A_{\mathrm{a}} \boldsymbol{x}_{\mathrm{a}}+B_{\mathrm{a}} Q_{\mathrm{c}} \\
& y_{\mathrm{a}}=C_{\mathrm{a}} x_{\mathrm{a}}+D_{\mathrm{a}} Q_{\mathrm{c}} \\
& \boldsymbol{A}_{\mathrm{a}}=\left[\begin{array}{cc}
0 & 1 \\
-0.01365 K^{2} & -0.3455 K
\end{array}\right], \quad \boldsymbol{B}_{\mathrm{a}}=\left[\begin{array}{l}
0 \\
1
\end{array}\right] \\
& C_{\mathrm{a}}=\left[\begin{array}{ll}
0.006825 K^{2} & 0.10805 K
\end{array}\right], \quad D_{\mathrm{a}}=0.5
\end{aligned}
$$

ここで， $y_{\mathrm{a}}$ は (5) 式の伝達関数 $C(\bar{s}) に Q_{\mathrm{c}}$ を入力し た時の出力を表す。

(2)〜 (6)式を(1)式に代入し, さらに操舵面駆動 のダイナミックスを表す状態方程式 $\left(\dot{x}_{\beta}=\boldsymbol{A}_{\beta} \boldsymbol{x}_{\beta}\right.$ $\left.+\boldsymbol{B}_{\boldsymbol{B}} u\right)$ を加え，センサ出力を $y$ と表すと次のような 状態方程式を得る。

$$
\begin{aligned}
& \dot{x}=\boldsymbol{A} \boldsymbol{x}+\boldsymbol{B} u \\
& y=\boldsymbol{C} \boldsymbol{x}
\end{aligned}
$$

ただし，

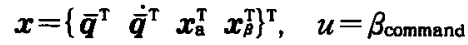

$$
\begin{aligned}
& \boldsymbol{A}=\left[\begin{array}{cccc}
0 & \boldsymbol{I}_{2} & 0 & 0 \\
-M^{\prime-1} \boldsymbol{K}^{\prime} & -M^{\prime-1} B^{\prime} & M^{\prime-1} D^{\prime} & M^{\prime-1} Q_{\beta}^{\prime} \\
B_{\mathrm{a}} E_{1} & B_{\mathrm{a}} E_{2} & A_{\mathrm{a}} & B_{\mathrm{a}} E_{\beta} \\
0 & 0 & 0 & A_{\beta}
\end{array}\right] \\
& B=\left[\begin{array}{llll}
0 & 0 & 0 & B_{B}
\end{array}\right]^{\mathrm{T}}, \quad C=\left[\begin{array}{llll}
C_{\mathrm{d}} & C_{\mathrm{s}} & 0 & 0
\end{array}\right] \\
& \boldsymbol{K}^{\prime}=\boldsymbol{K}_{\mathrm{s}}-\eta K^{2} \boldsymbol{R} E_{1} / 2 \\
& \boldsymbol{B}^{\prime}=-\eta K\left(\boldsymbol{R} \boldsymbol{E}_{2} / 2+\boldsymbol{B}_{\mathrm{nc}}\right) \\
& M^{\prime}=M_{\mathrm{s}}-\eta M_{\mathrm{nc}} \\
& D^{\prime}=\eta K R C_{\text {a }} \\
& \boldsymbol{Q}_{\boldsymbol{\beta}}^{\prime}=\eta\left(K \boldsymbol{R} \boldsymbol{E}_{\beta}+\boldsymbol{Q}_{\mathrm{nc \beta}}\right)
\end{aligned}
$$


センサ (S.P.) は弾性軸から後方 $b l$, 翼弦中心 (M. C.) 加ら後方 $b l^{\prime}=b(l+a)$ のところに置かれ, 翼の 変位あるいは速度を測定出力とする。このとき, 各出 力は下向きを正にとると，

$$
\begin{aligned}
& y_{\text {displacement }}=b(\bar{h}+l \alpha) \\
& y_{\text {speed }}=b(\overline{\bar{h}}+l \dot{\alpha})
\end{aligned}
$$

と表わされる．従って出力行列 $\boldsymbol{C}$ は翼の変位を観測 するか速度を観測するかにより次のように決まる。

変位出力: $C_{\mathrm{d}}=\left[\begin{array}{ll}b & b l\end{array}\right], C_{\mathrm{s}}=\left[\begin{array}{ll}0 & 0\end{array}\right]$

速度出力: $C_{\mathrm{d}}=\left[\begin{array}{ll}0 & 0\end{array}\right], C_{\mathrm{s}}=\left[\begin{array}{ll}b & b l\end{array}\right]$

上式からわかるように，速度を出力とする伝達関数で は変位出力の伝達関数に原点の零が付加されるだけで ある. 以下では変位センサの使用を仮定する.

操舵面舵角命令 $u$ からセンサ出力 $y$ までの伝達関 数は, 舵角命令 $u$ から舵角 $\beta$ までの伝達関数と舵角 及から出力 $y$ までの伝達関数とに分けられる。

$$
\frac{Y(s)}{U(s)}=\boldsymbol{C}(s \boldsymbol{I}-\boldsymbol{A})^{-1} \boldsymbol{B}=\frac{Y(s)}{\beta(s)} \frac{\beta(s)}{U(s)}
$$

以下では駆動系のダイナミックスを除いた伝達関数 $Y(s) / \beta(s)$ を検討する.

\section{3. センサ位置と零}

3.1 定常空気力での検討 定常空気力は翼変位に よる静的な力のみを考え, 翼変動と空気力の間の時間 遅れを無視して得られる空気力表現である.したがっ て空気力の時間遅れを表現する状熊変数は不要となり システムの次数は隇少する.この場合の操舵面舵角か らセンサ出力までの伝達関数は ( 7 ) 式で $\boldsymbol{E}_{2}, \boldsymbol{B}_{\mathrm{nc}}$ 等を 省略し, さらに $C(\bar{s})=1$ とおくと

$$
\frac{Y(s)}{\beta(s)_{\text {steady }}}=\frac{b\left(N_{1 s} s^{2}+N_{2 s}\right)}{s^{4}+D_{1 s} s^{2}+D_{2 s}}
$$

になる.ただし，

$$
\begin{aligned}
& N_{1 \mathrm{~s}}=\frac{\eta K^{2}}{r_{a}^{2}-x_{a}{ }^{2}}\left[\left(l^{\prime}-a\right)\left\{2\left(e+x_{a}\right) T_{10}-T_{15}\right\}\right. \\
& \left.-\left\{2\left(r_{a}^{2}+e x_{\alpha}\right) T_{10}-x_{a} T_{15}\right\}\right] \\
& N_{2 s}=\frac{\eta K^{2} \omega_{\alpha}^{2}}{r_{\alpha}^{2}-x_{\alpha}^{2}}\left[\left(l^{\prime}-a\right)\left(2 e T_{10}-T_{15}\right) \frac{\omega_{h}{ }^{2}}{\omega_{\alpha}{ }^{2}}\right. \\
& \left.-\left\{2 r_{\alpha}^{2} T_{10}-2 \pi \eta T_{15} \frac{K^{2}}{\omega_{\alpha}^{2}}\right\}\right] \\
& D_{1 \mathrm{~s}}=\frac{\omega_{a}^{2}}{r_{\alpha}^{2}-x_{\alpha}^{2}}\left[r_{\alpha}^{2}\left(1+\frac{\omega_{h}^{2}}{\omega_{\alpha}^{2}}\right)-2 \pi \eta\left(e+x_{\alpha}\right) \frac{K^{2}}{\omega_{\alpha}^{2}}\right] \\
& D_{2 s}=\frac{\omega_{h}{ }^{2} \omega_{\alpha}{ }^{2}}{r_{\alpha}{ }^{2}-x_{\alpha}{ }^{2}}\left[r_{\alpha}{ }^{2}-2 \pi \eta e \frac{K^{2}}{\omega_{\alpha}{ }^{2}}\right]
\end{aligned}
$$

(10)式より極 $p$ は，

$$
p^{2}=\left(-D_{1 s} \pm \sqrt{D_{1 s}{ }^{2}-4 D_{2 s}}\right) / 2
$$

極はセンサ位置 $l^{\prime}$ によらず流速 $K$ に対して一意に定 まる。これが複素平面上の右半面に現れると，翼はフ ラッタやダイバージェンスなどの不安定現象を生じ
る.フラッタ速度 $K=K_{\mathrm{F}}$ では曲げと㹉りの極が一致 することから，上式で $D_{1 \mathrm{~s}}{ }^{2}-4 D_{2 \mathrm{~s}}=0$ より

$$
\begin{aligned}
\left(\frac{K_{F}}{\omega_{\alpha}}\right)^{2}= & \frac{1}{2 \pi \eta}\left(\frac{r_{\alpha}}{x_{\alpha}+e}\right)^{2} \\
\cdot & {\left[x_{\alpha}+e+\left(x_{\alpha}-e+2 e \frac{x_{\alpha}{ }^{2}}{r_{\alpha}{ }^{2}}\right)\left(\frac{\omega_{h}}{\omega_{\alpha}}\right)^{2}\right.} \\
& -\frac{2 \omega_{h}}{\omega_{\alpha}}\left\{x_{\alpha}\left(1-\frac{x_{\alpha}{ }^{2}}{r_{\alpha}{ }^{2}}\right)\right. \\
\cdot & {\left.\left.\left[x_{\alpha}+e-e x_{\alpha}\left(1+\frac{e x_{\alpha}}{r_{\alpha}{ }^{2}}\right)\left(\frac{\omega_{h}}{\omega_{\alpha}}\right)^{2}\right]\right\}^{1 / 2}\right] }
\end{aligned}
$$

と求められる. 零 $z$ は,

$$
z^{2}=-N_{2 \mathrm{~s}} / N_{1 \mathrm{~s}}
$$

であり, 複素平面上の実軸か虚軸の原点対称な点にの み存在し，流速とセンサ位置によって決まる。

3.2 最小位相伝達関数を得るセンサ位置 舵角か らセンサ出力までの伝達関数が最小位相, つまり開右 半面に零が存在しない条件は $N_{2 \mathrm{~s}} / N_{1 \mathrm{~s}}>0$ である。こ の条件を分類すると次式のいずれか一方を満足すれば 零は開右半面に存在しない

$$
\left\{\begin{array}{l}
\left(l^{\prime}-a\right)\left(e+x_{a}+T^{\prime}\right)>r_{\alpha}{ }^{2}+x_{\alpha}\left(e+T^{\prime}\right) \\
\left(l^{\prime}-a\right)\left(e+T^{\prime}\right) \omega_{h}^{2} / \omega_{a}{ }^{2}>r_{a}{ }^{2}+2 T^{\prime} K^{2} / \mu \omega_{\alpha}{ }^{2}
\end{array}\right.
$$

$$
\left\{\begin{array}{l}
\left(l^{\prime}-a\right)\left(e+x_{\alpha}+T^{\prime}\right)<r_{\alpha}{ }^{2}+x_{\alpha}\left(e+T^{\prime}\right) \\
\left(l^{\prime}-a\right)\left(e+T^{\prime}\right) \omega_{h}^{2} / \omega_{\alpha}{ }^{2}<r_{a}^{2}+2 T^{\prime} K^{2} / \mu \omega_{a}{ }^{2}
\end{array}\right.
$$

ここで $T^{\prime}$ は，

$$
T^{\prime}=2 C_{\mathrm{M} \beta} / C_{\mathrm{L} \beta}=-T_{15} / 2 T_{10}
$$

であり，操舵面変位によって翼に生じるモーメントと 揚力の比である．次の值を定義する。

$$
\begin{aligned}
& l_{1}^{\prime}=\frac{r_{\alpha}^{2}+x_{\alpha}\left(e+T^{\prime}\right)}{e+x_{\alpha}+T^{\prime}}+a \\
& l_{2}^{\prime}=\frac{r_{\alpha}^{2}+2 T^{\prime} K^{2} / \mu \omega_{\alpha}{ }^{2}}{\left(e+T^{\prime}\right) \omega_{h}^{2} / \omega_{\alpha}^{2}}+a
\end{aligned}
$$

li は $N_{\mathrm{ls}}=0$ とするときのセンサ位置であり次のよう に解釉できる， $N_{1 \mathrm{~s}} \rightarrow 0$ とすると(14)式から $z \rightarrow \infty$ と なり． $s \rightarrow \infty に お け る(10)$ 式は 0 になる。従って, $l_{1}^{\prime}$ は振動数無限大の翼の振動を仮定する場合の振動の節 である。一方, $N_{2 \mathrm{~s}}=0$ とするときのセンサ位置であ

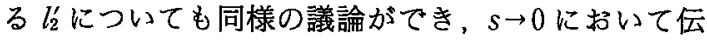
達関数が 0 になることから振動数 0 の翼の振動を仮定 する場合の振動の節であると解釈できる。このことか ら $l_{1}^{\prime}, l_{2}^{\prime}$ は伝達関数の最小位相性の境界にあたる出力 位置であり，これらの点を横切るときに伝達関数の位 相特性が変わる。特に $N_{2 s}=0$ となる流速は

$$
\left(\frac{K}{\omega_{a}}\right)^{2}=\frac{\mu}{2 T^{\prime}}\left[\left(l^{\prime}-a\right)\left(e+T^{\prime}\right)\left(\frac{\omega_{h}}{\omega_{a}}\right)^{2}-r_{\alpha}^{2}\right]
$$

と求められる. 以上により， $l_{1}^{\prime}, l_{2}^{\prime}$ の位置関係と $e$ 
$+T^{\prime}, e+x_{a}+T^{\prime}$ の正負によって最小位相になるセン サ位置の範囲が(15)式から決まり，その範囲は次の 4 通りに分けられる。

Case 1. $e+T^{\prime}<0, e+x_{a}+T^{\prime}<0$ のとき

$$
l^{\prime}<l_{1}^{\prime}, l^{\prime}<l_{2}^{\prime} \text { or } l^{\prime}>l_{1}^{\prime}, l^{\prime}>l_{2}^{\prime}
$$

Case 2. $e+T^{\prime}<0, e+x_{a}+T^{\prime}>0$ のとき

$$
l^{\prime}>l_{1}^{\prime}, l^{\prime}<l_{2}^{\prime} \text { or } l^{\prime}<l_{1}^{\prime}, l^{\prime}>l_{2}^{\prime}
$$

Case 3. $e+T^{\prime}>0, e+x_{a}+T^{\prime}<0$ のとき

$$
l^{\prime}<l_{1}^{\prime}, l^{\prime}>l_{2}^{\prime} \text { or } l^{\prime}>l_{1}^{\prime}, l^{\prime}<l_{2}^{\prime}
$$

Case 4. $e+T^{\prime}>0, e+x_{a}+T^{\prime}>0$ のとき

$$
l^{\prime}>l_{1}^{\prime}, l^{\prime}>l_{2}^{\prime} \text { or } l^{\prime}<l_{1}^{\prime}, l^{\prime}<l_{2}^{\prime}
$$

上式からわかるように，Case 1 と 4 では翼の特性 が異なるが，最小位相となるセンサ位置の範囲は同一

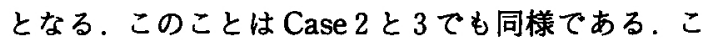

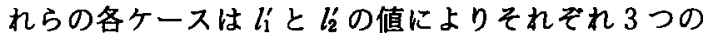
場合に細分化される。さらにセンサを翼上におく場 合，上式の範囲に加えて前縁 (L.E.) と操舵面ヒンジ の間にセンサがなくてはならないという制約がある. 以上の分類をもとに最小位相となるセンサ位置の範囲 が第 1 表にまとめられている（この図的表現は文献 5) 参照).

一般的な航空機の買構造諸元はほぼ第 2 表に示す範 囲にある ${ }^{6} . c=0.6 \sim 1.0, T^{\prime}<0$ とし，各ケースで最も 生じ易い場合について最小位相になるセンサ位置の範 囲を調へると，速度増加に対し次の矢印に示すように

第 1 表 最小位相伝達関数を与えるセンサ位置の籰囲

\begin{tabular}{|c|c|}
\hline 第 2 表 & $\begin{array}{l}\text { 一般的な航空機の } \\
\text { 㟺粠造諸元 }\end{array}$ \\
\hline$\mu$ & $16 \sim 60$ \\
\hline$r_{a}^{2}$ & $1 \sim 0.36$ \\
\hline$\omega_{n} / \omega_{a}$ & $0 \sim 0.5$ \\
\hline$a$ & $0 \sim-0.4$ \\
\hline$x_{\alpha}$ & $0 \sim 0.2$ \\
\hline
\end{tabular}

\begin{tabular}{lll}
\hline Cases* & \multicolumn{1}{c}{1 and 4} & \multicolumn{1}{c}{2 and 3} \\
\hline A $>$ & L.E. $\sim$ Hinge & No region \\
A & $l_{2}^{\prime} \sim$ Hinge & L.E. $\sim l_{2}^{\prime}$ \\
A & No region & L.E. $\sim$ Hinge \\
\hline B & $l_{1}^{\prime} \sim$ Hinge & L.E. $\sim l_{1}^{\prime}$ \\
B & L.E. $\sim l_{2}^{\prime}$ (or $\left.l_{1}^{\prime}\right)$ and & $l_{2}^{\prime} \sim l_{1}^{\prime}$ or \\
& $l_{1}(\mathbf{C}) \sim$ Hinge & $l_{1}^{\prime} \sim l_{2}^{\prime}$ \\
Bウ & L.E. $\sim l_{1}^{\prime}$ & $l_{1}^{\prime} \sim$ Hinge \\
\hline Cア & No region & L.E. $\sim$ Hinge \\
Cイ & L.E. $\sim l_{2}^{\prime}$ & $l_{2}^{\prime} \sim$ Hinge \\
Cウ & L.E. $\sim$ Hinge & No region \\
\hline
\end{tabular}

\footnotetext{
${ }^{*} \mathrm{~A}: l_{1}^{\prime}<-1, \mathrm{~B}:-1<l_{1}^{\prime}<c, \mathrm{C}: l_{1}^{\prime}>c$,

ア: $l_{2}^{\prime}<-1$, イ $:-1<l_{2}^{\prime}<c$, ウ: $l_{2}^{\prime}>c$.
}

\begin{tabular}{cc} 
第 3 表 & 基䧿造諸元例 \\
\hline$\mu$ & 40 \\
$r_{a}{ }^{2}$ & 0.25 \\
$\omega_{h} / \omega_{a}$ & 0.5 \\
$a$ & -0.4 \\
$x_{a}$ & 0.2 \\
$c$ & 0.6
\end{tabular}

変化する（ $x_{\alpha}>0$ のため Case 3 の場合はない）。

Case 1. lín前緑より前に位置する場合， $l_{2}^{\prime}$ は速 度増加とともに前方から後方に移動する．従って最小 位相を与える範囲は，
$\mathrm{A}$ ア $\rightarrow \mathrm{A}$ イ $\rightarrow \mathrm{A}$ ウ と変化する

Case 2. $l_{1}^{\prime}$ が後縁より後に位置する場合， l' は前 方から後方に移動するため簀瞳は，

$\mathrm{C}$ ア $\rightarrow \mathrm{C}$ イ $\rightarrow \mathrm{C}$ ウ と変化する.

Case 4. $l_{1}^{\prime}$ が後縁より後に位置する場合， $l_{2}^{\prime}$ は後 方から前方に移動するため範囲は，

$\mathrm{C}$ ウ $\rightarrow \mathrm{C} 1 \rightarrow \mathrm{C} \boldsymbol{\gamma}$ と変化する.

代表的な例として第 3 表に示す後縁操舵面付き二次 元平板翼の構造諸元を基にして $e+T^{\prime}, e+x_{a}+T^{\prime}$, $l_{1}^{\prime}, l_{2}^{\prime}$ を求めると,

$$
\begin{aligned}
& e+T^{\prime}=-0.2706<0 \\
& e+x_{\alpha}+T^{\prime}=-0.0706<0 \\
& l_{1}^{\prime}=-3.1745<-1.0 \\
& l_{2}^{\prime}=-4.0955+0.2739\left(U / b \omega_{a}\right)^{2}
\end{aligned}
$$

となり，定常空気力の検討ではこの異構造諸元は Case 1，Aにあたる。この場合, 最小位相になるセン サ位置の範囲は第 2 図に示すようなハッチングした翼

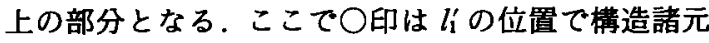
により決まり，口印は $l_{2}^{\prime}$ の位㯰で，その他に流速の 関数である。これらの結果から，現在の一般的な航空 機の翼構造諸元について後縁操舵面による能動制御を 行う場合, $e+T^{\prime}, e+x_{a}+T^{\prime}$ の值に応して Case 1 と 2 では操舵面ヒンシ，Case 4 では前縁にセンサを おくことによって最小位相になる速度域を最大にとれ ることがわかる。

3.3 非定常空気力の影䈪 非定常空気力における 操舵面舵角命令からセンサ出力までの伝達関数は分 母，分子とも 6 次式となり，定常空気力のように極， 零を代数的に求めることは不可能である。したがっ て，零の挙動及び最小位相になるセンサ位置の範囲を 個々の翼構造諸元について調べなければならない．以 下では第 3 表に示された構造諸元を例にして，センサ

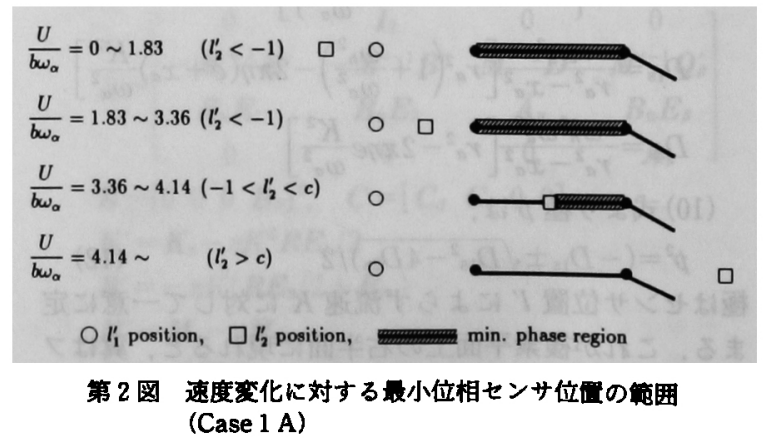




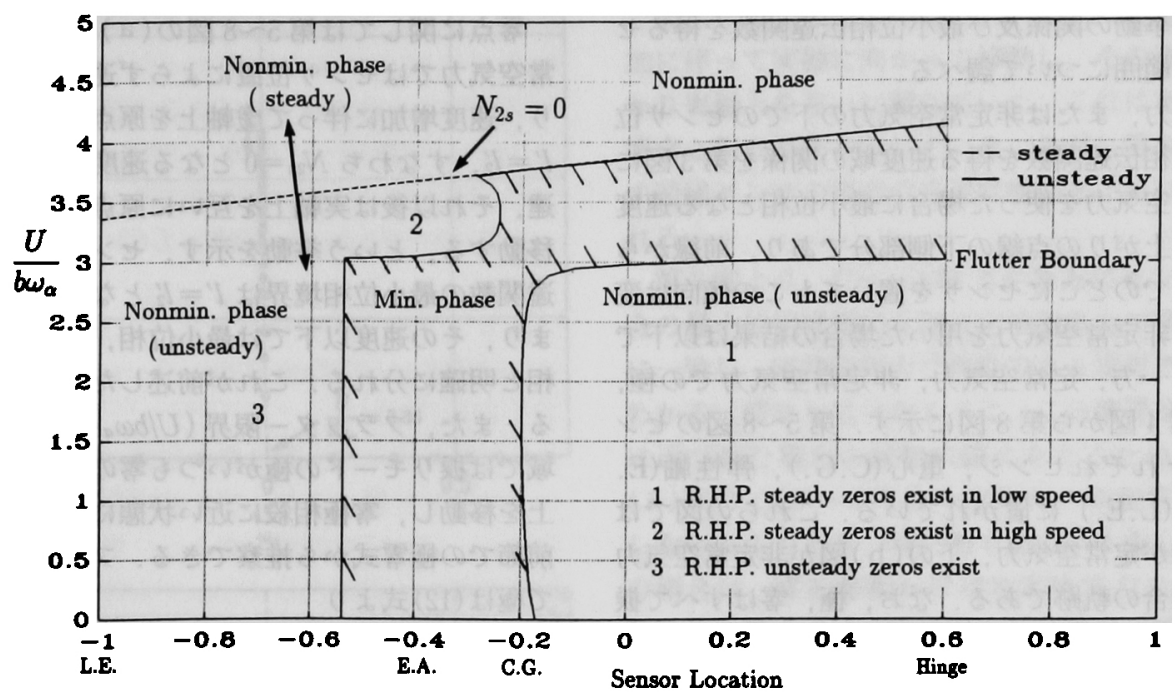

第 3 図 最小位相になるセンサ位置と速度域の関係
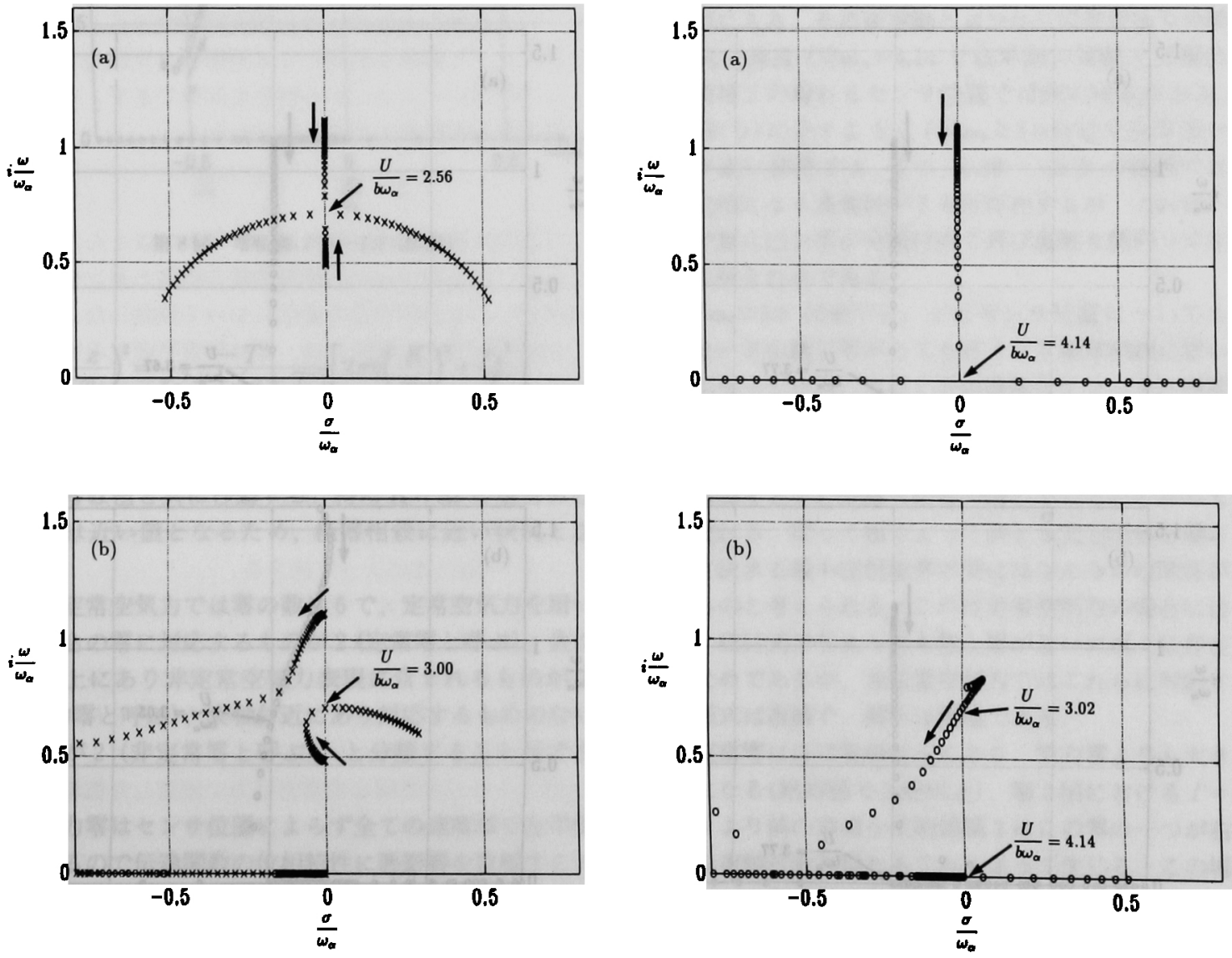

第 4 图 極轨跡

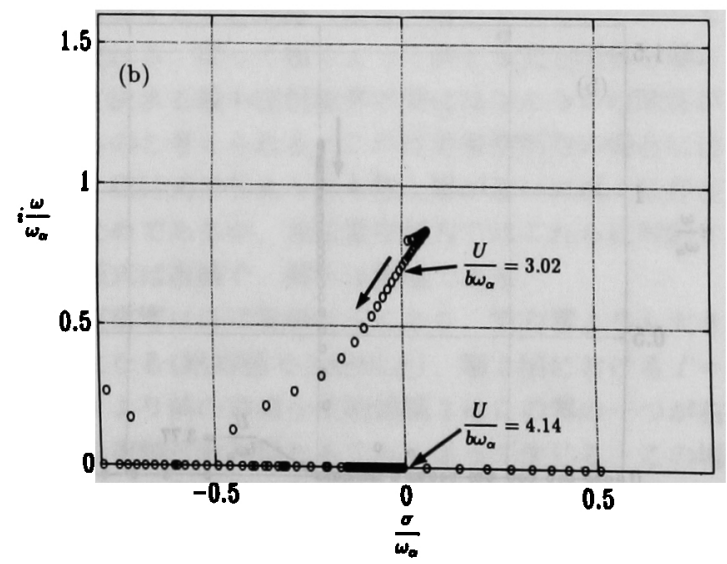

第 5 図 零轨跡 $l^{\prime}=0.6$ (ヒンジ) 
位置と零の挙動の関係及び最小位相伝達関数を得るセ ンサ位置の範囲について調べる。

定常空気力，または非定常空気力の下でのセンサ位 置と最小位相伝達関数を得る速度域の関係を第 3 図に 示す．定常空気力を使った場合に最小位相となる速度 域は図で右上がりの点線の下側部分であり，前縁から ヒンジ点までのどこにセンサを置いてもこの傾向は変 わらない，非定常空気力を用いた場合の結果は以下で 説明する. 一方, 定常空気力, 非定常空気力での極, 零軌跡を第 4 図から第 8 図に示す. 第 5 8 図のセン サ位置はそれぞれヒンジ，重心(C.G.)，弾性軸(E. A.)，前縁(L.E.) に置かれている.これらの図では 上の (a) 図が定常空気力, 下の (b) 図が非定常空気力 を用いた場合の軌跡である．なお，極，零はすへて㹉 り固有振動数 $\omega_{a}$ でスケーリングしてある. 第 4 図の 極軌跡からわかるように,この翼諸元では $U / b \omega_{a}=$ 3.00 で曲げモードが不安定となるフラッターを起こ す.一方, 定常空気力では安全側のフラッター速度を 与えている.
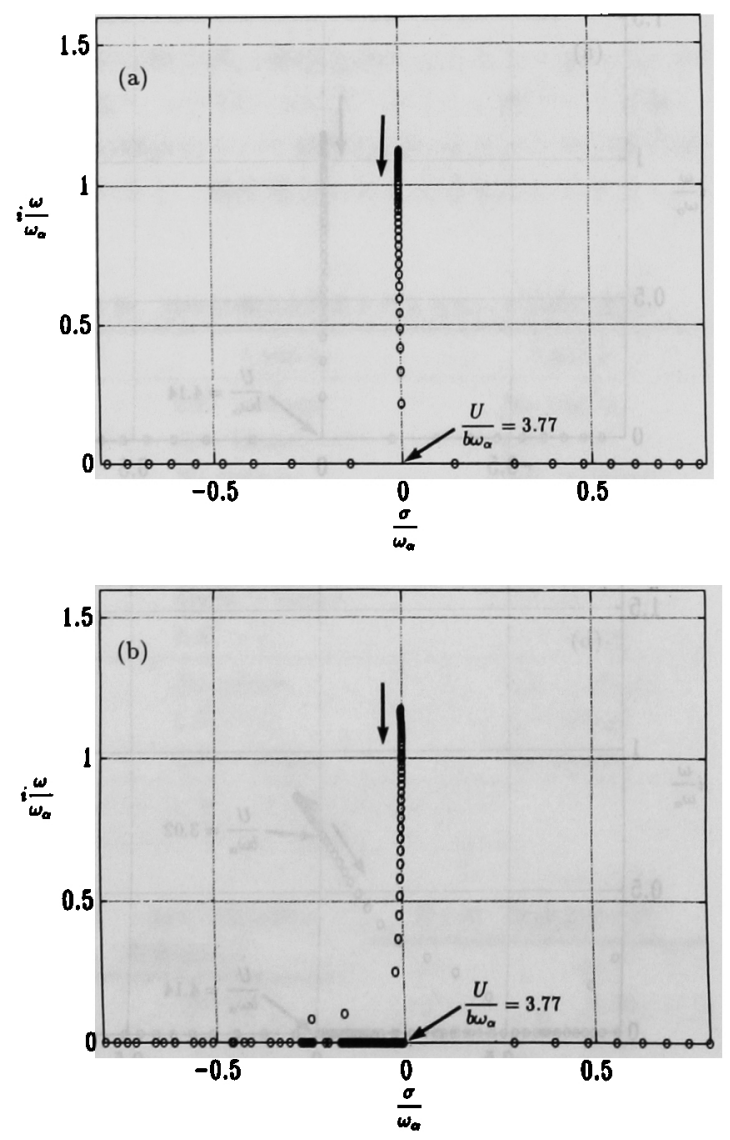

第 6 図 雾軌跡 $l^{\prime}=-0.2($ 重心)
零点に関しては第 5〜8図の(a)に示されている定 常空気力ではセンサ位置によらず速度 0 で虚軸上にあ り，速度増加に伴って虚軸上を原点に向かって移動し $l^{\prime}=l_{2}^{\prime}$ ，すなわち $N_{2 s}=0$ となる速度 (18) 式で原点に到 達, それ以後は実軸上を互いに原点から離れる方向に 移動する，という挙動を示す。センサ位置に対する伝 達関数の最小位相境界は $l^{\prime}=l_{2}^{\prime}$ となる速度によって決 まり，その速度以下では最小位相，以上では非最小位 相と明確に分れる。これが前述した第 3 図の点線であ る. また，フラッター限界 $\left(U / b \omega_{a}=2.56\right)$ 以下の速度 域では㨭りモードの極がいつも零の近くにあって虚軸 上を移動し，零極相殺に近い状態にある。このことは 前節での極零式から推察できる.フラッター速度付近 で極は(12)式より

$$
\begin{aligned}
\left(\frac{\not p}{\omega_{a}}\right)^{2}= & \frac{x_{a}+e}{2\left(r_{a}^{2}-x_{a}^{2}\right)}\left[2 \pi \eta\left(\frac{K}{\omega_{a}}\right)^{2}\right. \\
& \left.-\frac{r_{a}^{2}}{x_{a}+e}\left(1+\frac{\omega_{h}^{2}}{\omega_{a}^{2}}\right)\right]
\end{aligned}
$$

と書け，一方，雺は(14)式から簡単化のため $l^{\prime}=a$ の
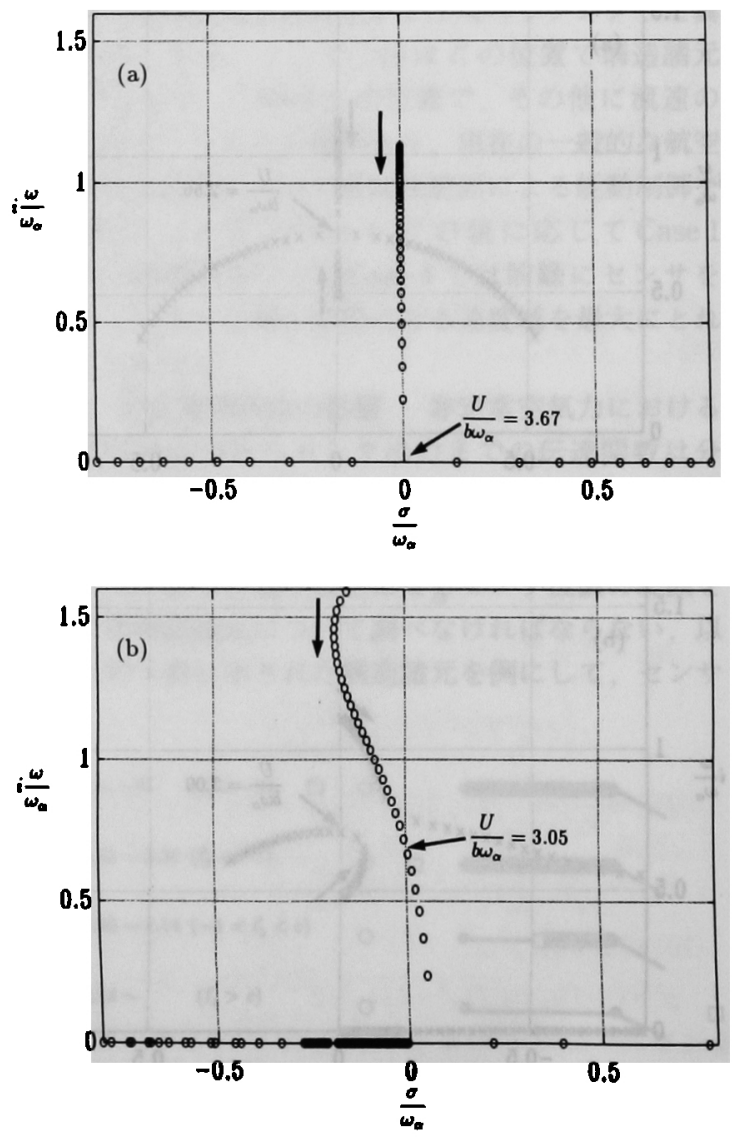

第 7 図 雺軌跡 $l^{\prime}=-0.4$ (弾性軸) 

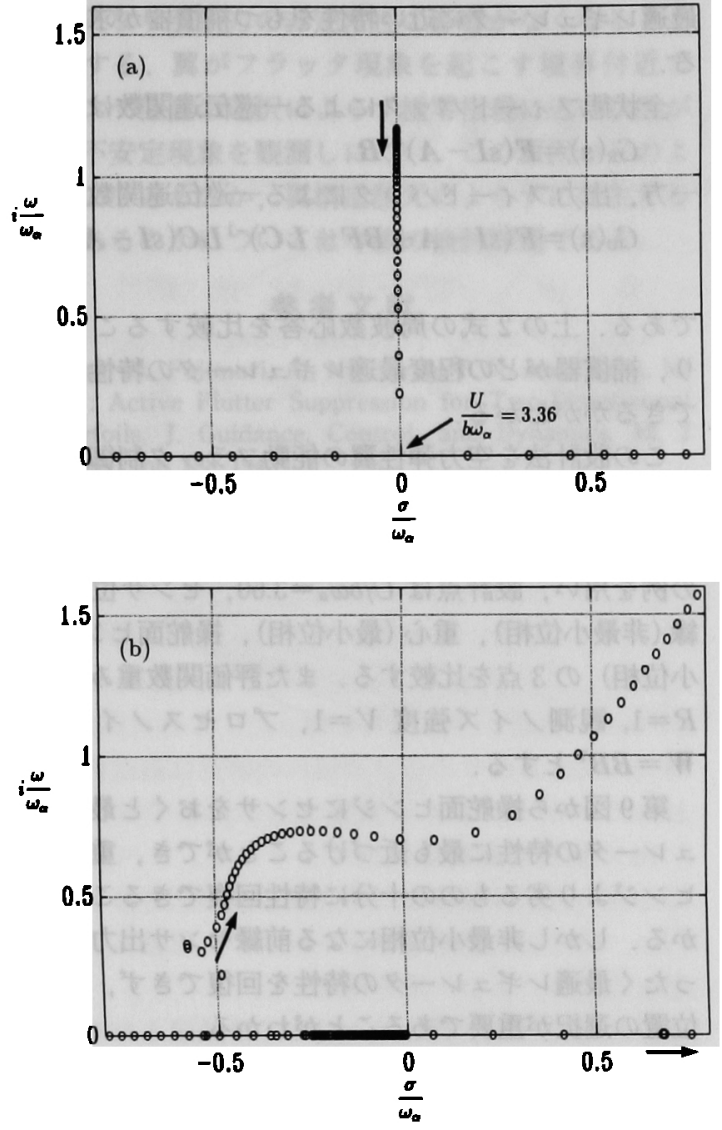

第 8 図 零軌跡 $l^{\prime}=-1.0$ (前縁)

場合,

$$
\left(\frac{z}{\omega_{a}}\right)^{2}=\frac{-T^{\prime}}{r_{a}^{2}+x_{a}\left(e+T^{\prime}\right)}\left[2 \pi \eta\left(\frac{K}{\omega_{a}}\right)^{2}+\frac{r_{a}^{2}}{T^{\prime}}\right]
$$

となる.この両式の $K$ の関数形は似かよっているた め，零は極と共に移動する．特に $K \cong K_{\mathrm{F}}$ の場合には 両者は近い值となるため，極零相殺に近い状況とな る.

非定常空気力では零の数は 6 て，定常空気力を用い た場合の零に対応するものが 2 (定常零と呼ぶ)，負の 実軸上にあり非定常空気力表現に含まれるものが 2 (空力零と呼ぶ)，実軸付近にあり対応するもののない ものが 2 (非定常零と呼ぶ)，と分類することができ る.

空力零はセンサ位固によらず全ての速度域で左半面 にあるので云達関数の位相特性に悪影響を及ほすこと はない. 空力極との極零相殺は起きるとしても左半面 での現象であり，また空力極はもともと観測できない のでこのことによる不利益は生じない，
第 5〜7図(b)にみられるように，定常零は速度增 加に伴って実軸に向かって移動し，その後実軸とぶつ かり実軸上を互いに離れていく．これは定常空気力の 場合と似た挙動を示している．ただし第 8 図（b)に示 す前縁センサの場合のみ速度增加とともに実軸から離 れる。

第 3 図より, $l^{\prime}=-0.29$ より後方にセンサをおく場 合の最小位相境界の上限は定常空気力で推定した上限 に一致し，定常空気力で推定できる境界であることが わかる．前にも述べたように，この境界は振動数を零

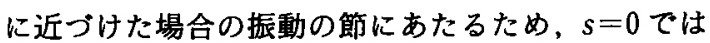
(5) 式の $C(\bar{s})=1$ となり空気力の非定常性には依存 しないからである．特に第 6 図に示す重心位置センサ の場合は, 零の挙動がほほ定常空気力のそれに一致 し，この場合には定常空気力での検討に妥当性のある ことがわかる.しかし他のセンサ位置では第 3 図の $1 ， 2$ で示すような非最小位相になる速度域がある。

領域 1 の現れるセンサ位置では，重心位置付近のわ ずかな箟囲を除いて第 5 図（b）に示すように零は低速 域で右半面にあり，U/b $\omega_{\alpha} \cong 3.0$ 付近で虚軸を横断し， 左半面に入る.その後実軸とぶつかり定常空気力の場 合と同じ速度 $U / b \omega_{a}=4.14$ で右半面の害軸上に現れ る. 領域 2 の現れるセンサ位置では逆の現象がおき， 第 7 図 (b)に示すように $U / b \omega_{a} \cong 3.0$ 付近で左半面か ら右半面に移動する. $l^{\prime}=-0.29 \sim-0.24$ の範囲では 最小位相になる速度域が 2 力所存在するが、これは一 度右半面に出た零が実軸付近で再び虚軸を横切って左 半面に戻るためである。

$U / b \omega_{a} \cong 3.0$ 付近では，どのセンサ位置についても 曲げモードの極と零がとても近くなり極零相殺に近い 状態になっている．また，この速度はフラッター速度 や領域 1，2 の存在するセンサ位置で位相特性が変わ る速度にほ海等しい。このことは第 3 図でフラッタ限 界が領域 1 と 2 の境界とほほ一致していることからも 読み取れる．従って極によって決まる安定境界と零に よって決まる最小位相境界の間にはなんらかの関係が あるものと考えられる。これは定常空気力の場合には (20)，(21)式で与えられる極と零が互いに近くに存在 するためであるが，非定常空気力ではこれらに対応す る関係式は複雑で，解析は困難である．

非定常零はほほ実軸付近にあり，空力零よりも大き い値になる(絶対值て 3 倍以上). 第 3 図における $l^{\prime}=$ -0.54 より前の非最小位相領域 3 はこの零の一つが右 半面の実軸付近に現れることによって生じる。この場 合，センサ位直を前縁方向に移動するにつれ，第 7 図 (b)の虚軸付近の定常零軌跡は左に回転したものとな り，センサが前縁付近における定常零に対応する零の 
挙動は第 8 図に示すように定常空気力ての挙動と全く 異なる。

極に対応する安定領域が非定常空気力の下では定常 空気力よりも広がるのに対して，最小位相領域は非定 常空気力のほうが㹨くなり，定常空気力での推定通り の最小位相領域が得られるセンサ位置は重心位置付近 のわずかな範囲に限られる。

\section{4. センサ位筧と制御}

翼の能動制御系設計法として線形時不変の制御対象 に対する LQG/LTR 設計法を適用することを考え， センサ位置と制御性能の関係を調べる。

LQG/LTR 設計法ては，まず全状態フィードバッ クを仮定して評価関数を最小にする最適レギュレータ ゲイン $\boldsymbol{F}$ を求め，実際に観測できる状態が限られる ことを考慮し入力と観測出力から状態推定器のゲイン $L$ を求める。このとき状態推定器併用最適レギュレ ータでは原最適レギュレータのロバスト特性が保存さ れないが、プラントの制御入力に架空のノイス $q \boldsymbol{B} \boldsymbol{B}^{\mathrm{T}}$ を付加し $q$ を大きくするループ特性回復操作により，
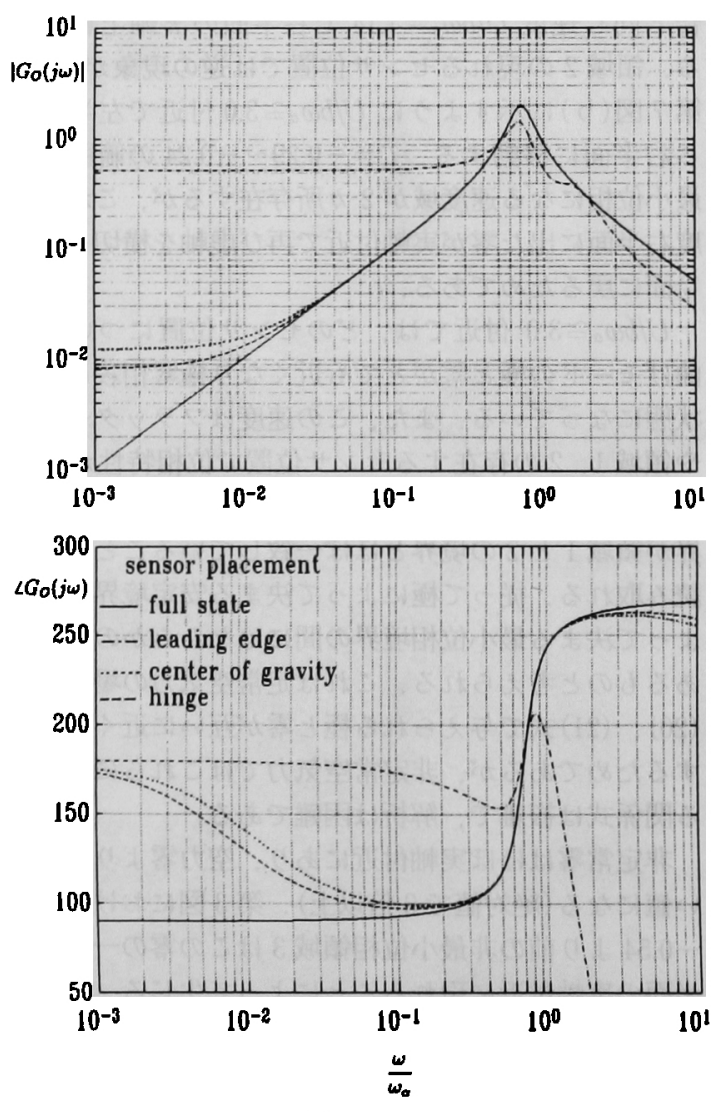

第 9 図 $G_{0}(s)$ のループ特性回復
最適レギュレータに近い特性をもつ補偵器が求められ る.

全状態フィードバックによる一巡伝達関数は，

$$
G_{\mathbb{R}}(s)=F(s I-A)^{-1} B
$$

一方, 出力フィードバックによる一巡伝達関数は,

$$
G_{0}(s)=F(s I-A+B F+L C)^{-1} L C(s I-A)^{-1} B
$$

である.上の 2 式の周波数応答を比較することによ り, 補償器がどの程度最適レギュレータの特性を回復 できるかがわかる。

この設計法を空力弾性翼の能動フラッタ制御に適用 し, センサ位置により一巡伝達関数がどう変わるかを 調へる.（7)式を制御対象とし, 翼構造諸元は第 3 表 の例を用い, 設計点は $U / b \omega_{a}=3.60$, センサ位置は前 緑 (非最小位相)，重心(最小位相), 操舵面ヒンジ(最 小位相）の 3 点を比較する. また評価関数重み $\boldsymbol{Q}=0$, $R=1$, 観測ノイズ強度 $V=1$, プロセスノイズ強度 $\boldsymbol{W}=\boldsymbol{B} \boldsymbol{B}^{\mathrm{T}}$ とする.

第 9 図から操舵面ヒンジにセンサをおくと最適レギ ユレータの特性に最も近づけることができ，重心でも ヒンジより劣るものの十分に特性回復できることがわ かる. しかし非最小位相になる前縁センサ出力ではま ったく最適レギュレータの特性を回復できず，センサ 位置の選択が重要であることがわかる.

\section{5. 結論}

空力弾性翼の能動制御において今までほとんど注目 されることのなかった伝達関数零の挙動とセンサ位置 の選択による位相特性の変化について検討した。

定常空気力での検討では，零は複素平面上の実軸か 虚軸の原点対称な点にのみ存在し，その挙動は翼構造 諸元，流速に加えてセンサ位置で決まる．また，最小 位相になるセンサ位置の篭囲は、翼の振動数が無限大 または零である場合に振動の節を与える点である $l_{1}^{\prime}$ と $l_{2}^{\prime}$, 弾性軸位置, 重心位置, および操秺面の発生乇 ーメント/揚力比によって決まる。

非定常空気力では，定常零に対応する零の他, 非定 常空気力による零と定常空気力では対応するもののな い零が存在する：定常零に対応する零は, 空気力の減 衰性や見かけの質量効果の偋響であるとおもわれる蛇 行以外は定常零と似た挙動を示すが, 蛇行により最小 位相になる速度領域は定常空気力て推定した領域より 減少する．特に静止状態からある速度まで非最小位相 でその後最小位相になるセンサ位置が存在するため， 最小位相の上限を求めるだけでは不充分である。ま た，定常零に対応する零が複素平面の右半平面に現れ る速度は空気力によらず同じになる。これは運動が非 
振動的になり空気力の非定常性の影響がなくなること に対応する。翼がフラッタ現象を起こす境界付近て は，センサ位置の選択によらず極零相殺に近い状況が 発生し不安定現象を観測しにくい，この原因がどのよ うなものであるのか，翼構造諸元によらずに発生する 現象であるのかについては今後の検討課題である.

\section{参考文献}

1) Ohta, H., Fujimori, A., Nikiforuk, P. N. and Gupta, M. M. : Active Flutter Suppression for Two-Dimensional Airfoils, J. Guidance, Control, and Dynamics, 12, 2 (1989), pp. 188-194.
2) Edwards, J. W., Breakwell, J. V. and Bryson, A. E., Jr. : Active Flutter Control Using Generalized Unsteady Aerodynamic Theory, J. of Guidance and Control, 1, 1 (1978), pp. 32-40.

3) Liebst, B. S. : Accelerometer Placement in Active Flutter Suppression Systems, J. Guidance, Control, and Dynamics, 10, 5 (1987), pp. 441-446.

4) Theodorsen, T. : General Theory of Aerodynamic Instability and the Mechanism of Flutter, NACA Rept. No. 496, 1935 .

5）太田裕文，山田雅隆：空力弾性翼の能動制御におけるセン サ位置と零点, 計測自動制御学会第 11 回誘導制御シンポジ ウム, 1994, pp. 175-182.

6）川島孝幸, 池田 健 : 二次元翼のフラッタ解析とその経験 式, 日本航空宇宙学会誌, 27 (1979), pp. 268-273. 